\title{
HETEROSTEMON AMORIS (LEGUMINOSAE, DETARIOIDEAE), A NEW SPECIES FROM COLOMBIA AND A KEY TO THE SPECIES OF HETEROSTEMON
}

\author{
Andrés Fonseca-Cortés
}

Independent researcher, Bogotá D.C., Colombia; deafonsecaco@unal.edu.co (author for correspondence).

\begin{abstract}
Fonseca-Cortés, A. 2021. Heterostemon amoris (Leguminosae, Detarioideae), a new species from Colombia and a key to the species of Heterostemon. Darwiniana, nueva serie 9(2): 312-319.

Heterostemon amoris a new species from Colombia is described, illustrated, and a key to the species of the genus is presented. Heterostemon amoris is characterized by its leaves with 5-7 pairs of leaflets, basal pair of leaflets $0.6-0.8 \times 0.4-0.6 \mathrm{~cm}$, considerably smaller and falcate, intermediate leaflets $3.8-5.5 \times 1.1-2.0 \mathrm{~cm}$, ovate to obovate, and terminal pair of leaflets $2.0-2.3 \times 0.7-0.8 \mathrm{~cm}$, ovate, shorter than the intermediate ones. This new species is only known from four localities in the departments of Guainía and Vaupés.
\end{abstract}

Keywords. Brownea clade; Fabaceae; Guiana shield flora.

Resumen. Fonseca-Cortés, A. 2021. Heterostemon amoris (Leguminosae, Detarioideae), una nueva especie de Colombia y una clave para las especies de Heterostemon. Darwiniana, nueva serie 9(2): 312-319.

Se describe e ilustra Heterostemon amoris, una nueva especie de Colombia y se presenta una clave para las especies del género. Heterostemon amoris se caracteriza por sus hojas con 5-7 pares de folíolos, par basal de $0,6-0,8 \times 0,4-0,6 \mathrm{~cm}$, falcados y considerablemente más pequeños que los demás, folíolos intermedios de 3,8-5,5 × 1,1-2,0 cm, ovados a obovados, y par terminal de 2,0-2,3 × 0,7-0,8 cm, ovados y más pequeños que los intermedios. Esta nueva especie solo se conoce para cuatro localidades en los departamentos de Guainía y Vaupés.

Palabras clave. Clado Brownea; Fabaceae; flora del Escudo Guayanés.

\section{INTRODUCTION}

Heterostemon Desf. is a small neotropical genus with seven species endemic to northern South America, mainly to the Guiana shield and the Amazonia (Cowan, 1976). Recently, Redden et al. (2018) evidenced that Heterostemon is monophyletic and it is nested in the Brownea clade, sister to genus Paloue Ducke.

Heterostemon species are trees with short terminal, caulifloral, or ramigerous racemes, most species have lilac flowers with white stripes in the dorsal petal. The flowers have a hypanthium $1.2-4.5 \mathrm{~cm}$ long, four sepals and five or generally three (two absent or reduced to petalodia) petals, nine (three fertile and six infertile) white or pink stamens, with the basal part fused and forming a long sheath, and a gynophore (Cowan, 1976; Redden \& Herendeen, 2006). The leaf morphology in Heterostemon is species specific, which facilitates the identification of sterile material (Cowan, 1976). This genus could be confused with Brachycylix (Harms) R.S. Cowan or Paloue Aubl. However, Brachycylix presents pendulous long racemes, a brief hypanthium up to $1 \mathrm{~cm}$ long, and five fertile stamens and four staminodes (Redden $\&$ Herendeen, 2006); and Paloue presents white or red flowers, nine fertile stamens, sometimes three fertile plus six staminodes, white or red, fused only in the base (Redden et al., 2018). 
Despite Cowan \& Berry (1998) reported that Heterostemon presents only one petal, all the species of this genus present five or three petals (Cowan 1976; Redden \& Herendeen, 2006), the only genus of the Brownea clade with one petal is Macrolobium Schreb. (Mackinder, 2005; Redden \& Herendeen, 2006; Murphy et al., 2018).

There is a complete monographic revision of Heterostemon by Cowan (1976), plus local treatments by Bentham (1871) for Brazil, Sandwith (1939) for the British Guiana, and Cowan \& Berry (1998) for the Venezuelan Guayana. In Colombia, there are three species present in the departments of Amazonia, Caquetá, Guainía, Vaupés and Vichada (Gradstein, 2016).

A new species of Heterostemon endemic to Colombia is here described and illustrated, and morphological notes about similar sympatric species are provided, plus information on geographical distribution, habitat and IUCN conservation status.

\section{MATERIALS AND METHODS}

To identify the specimens pertinent literature on the taxonomy of the subfamily Detariodeae was consulted (Quiñones, 2005; Mackinder, 2005; Redden et al. 2018). For the circumscription of Heterostemon, Cowan (1976) was followed. For the elaboration of the description, plant organs were measured with digital callipers with an accuracy of $0.01 \mathrm{~mm}$. For the elaboration of the key, species protologues available at BHL website (https://www.biodiversitylibrary.org/) were analyzed, plus types specimen images available at JSTOR PLANTS website (http://plants.jstor.org). The physical collections housed in $\mathrm{COAH}$ and the virtual collections from COL, F, FMB, K, MO, NY, $\mathrm{P}, \mathrm{RB}, \mathrm{US}$, and $\mathrm{W}$ (herbarium acronyms follow Thiers, 2021) were analyzed. The morphological species concept was followed (McDade, 1995; Wiens \& Servedio, 2000; de Queiroz, 2007). In order to determine the conservation status of the species according to IUCN categories and criteria (IUCN 2019), the extent of occurrence (EOO) and area of occupancy (AOO) with a cell width of 2 $\mathrm{km}$ were calculated, using the GeoCAT platform (http://geocat.kew.org/).

\section{TAXONOMIC TREATMENT}

Heterostemon amoris Fonseca-Cortés, sp. nov. TYPE: Colombia, Guanía, Pto. Inírida, resguardo indígena Almidón-La Ceiba, alrededores de la comunidad La Ceiba, bosque de tierra firme, 80 m, 21-III-1998, P. Franco, G. Galeano, J. Murillo \& J. Jácome 6030 (holotype, COAH028311!; isotypes, MO-04975792!). Figs. 1, 2.

Diagnosis. Heterostemon amoris is morphologically similar to $H$. mimosoides Desf., from which it differs by its leaves with 5-7 pairs of leaflets (vs. 7-27 pairs), ovate to obovate (vs. oblong), terminal leaflets $3.8-5.5 \times 1.1-2.0 \mathrm{~cm}$ (vs. 1.2-2.7 $\times 0.3-0.5 \mathrm{~cm}$ ), and basal leaflets considerably smaller and falcate (vs. basal leaflets only slightly shorter and of similar shape to the remaining leaflets).

Tree to $13 \mathrm{~m}$ tall, trunk to $60 \mathrm{~cm}$ in diameter, branches reddish, glabrous to brown puberulous. Stipules 0.1-0.2 $\times 0.1-0.2 \mathrm{~cm}$, lanceolate, glabrous, deciduous. Leaves compound, 8.5-10.2 $\times$ 5.0-5.8 $\mathrm{cm}$; petiole $0.4-0.6 \mathrm{~cm}$ long, pulvinulate, glabrous to brown puberulous; rachis $3.5-4.6 \mathrm{~cm}$ long, winged; petiolule $0.1-0.2 \mathrm{~cm}$ long, pulvinulate, glabrous; leaflets 5-7 pairs, paripinnate, glabrous; each leaflet with asymmetrical base, acuminate or rarely slightly emarginate apex, with 1-2 small glands in the lamina, venation eucamptodromous with 10-16 pairs of secondary nerves, the central one prominent on abaxial surface; basal pair of leaflets considerably shorter than the rest, 0.6-0.8 $\times 0.4-0.6 \mathrm{~cm}$, falcate, $3-5$ intermediate pairs of leaflets $3.8-5.5 \times 1.1-2.0 \mathrm{~cm}$, ovate to obovate, terminal pair of leaflets $2.0-2.3 \times 0.7$ $0.8 \mathrm{~cm}$, ovate, shorter than the intermediate ones. Inflorescence $3-5 \mathrm{~cm}$ long, terminal, racemose, peduncle $0.3-1.0 \mathrm{~cm}$ long, glabrous; flowers $6-7 \mathrm{~cm}$ long, bracts $0.2-0.4 \times 0.1-0.3 \mathrm{~cm}$, triangular, glabrous to brown puberulous, bracteoles $0.3-0.4 \times 0.2-0.3 \mathrm{~cm}$ long, deltoid, glabrous, pedicel $1.0-1.3 \mathrm{~cm}$ long, hypanthium 2.0-3.6 cm long, cylindrical, glabrous; sepals four, 3-4 × 0.5-0.9 cm, obovate, apex mucronate, glabrous; petals three, $3-4 \times 2.0-2.5 \mathrm{~cm}$, lilac, dorsal one with white longitudinal stripes, truncate or slightly emarginate; stamens nine of which six are staminodes, $6-7 \times 0.6-1.0 \mathrm{~cm}$, 

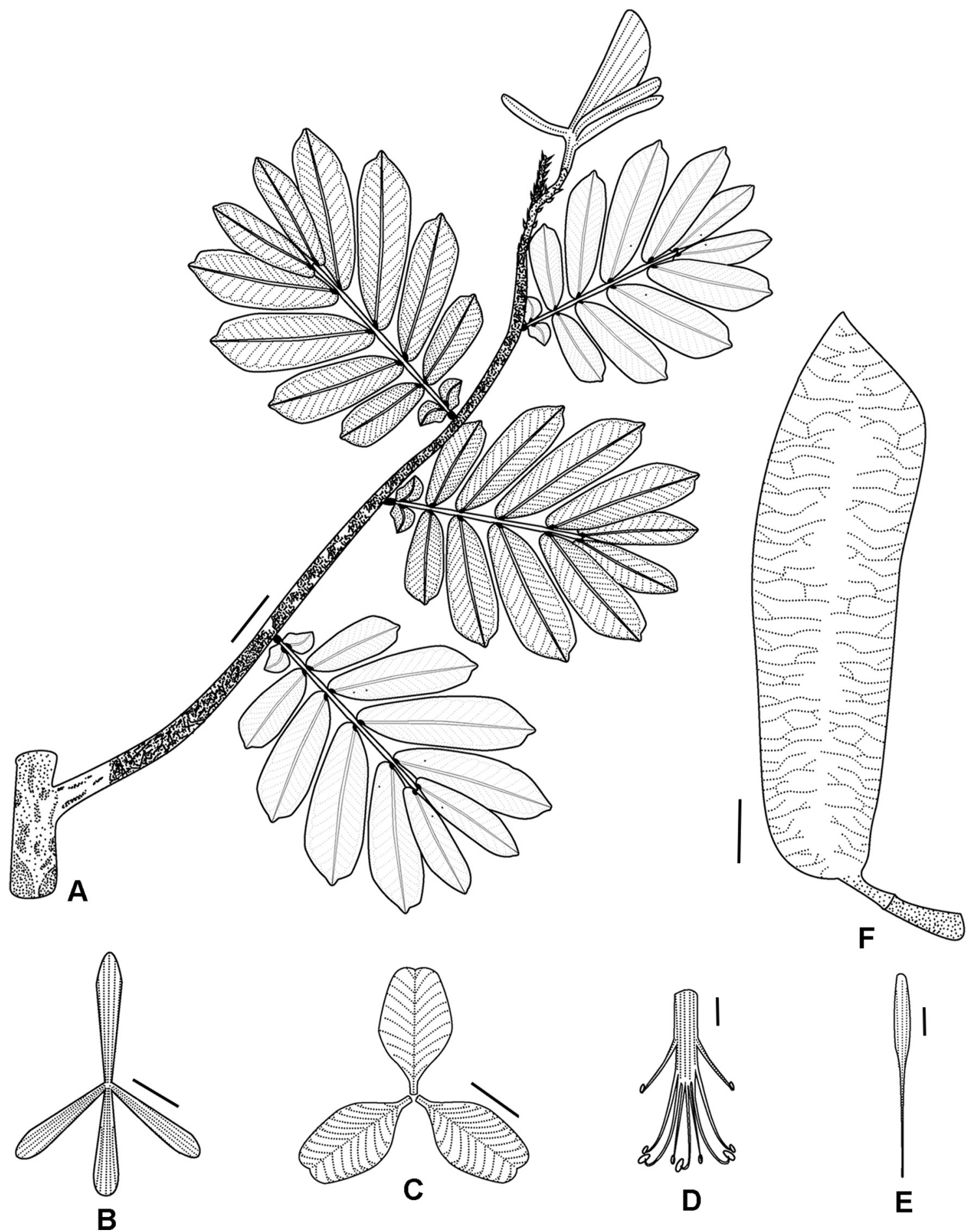

Fig. 1. Heterostemon amoris. A, branch. B, sepals. C, petals. D, stamens. E, gynoecium. F, fruit. A-E from $P$. Franco et al. 6030 (holotype COAH), F from P. Franco et al. 6030 (isotype MO). Scale bar: $2 \mathrm{~cm}$. Illustrated by Andrés Fonseca-Cortés. 

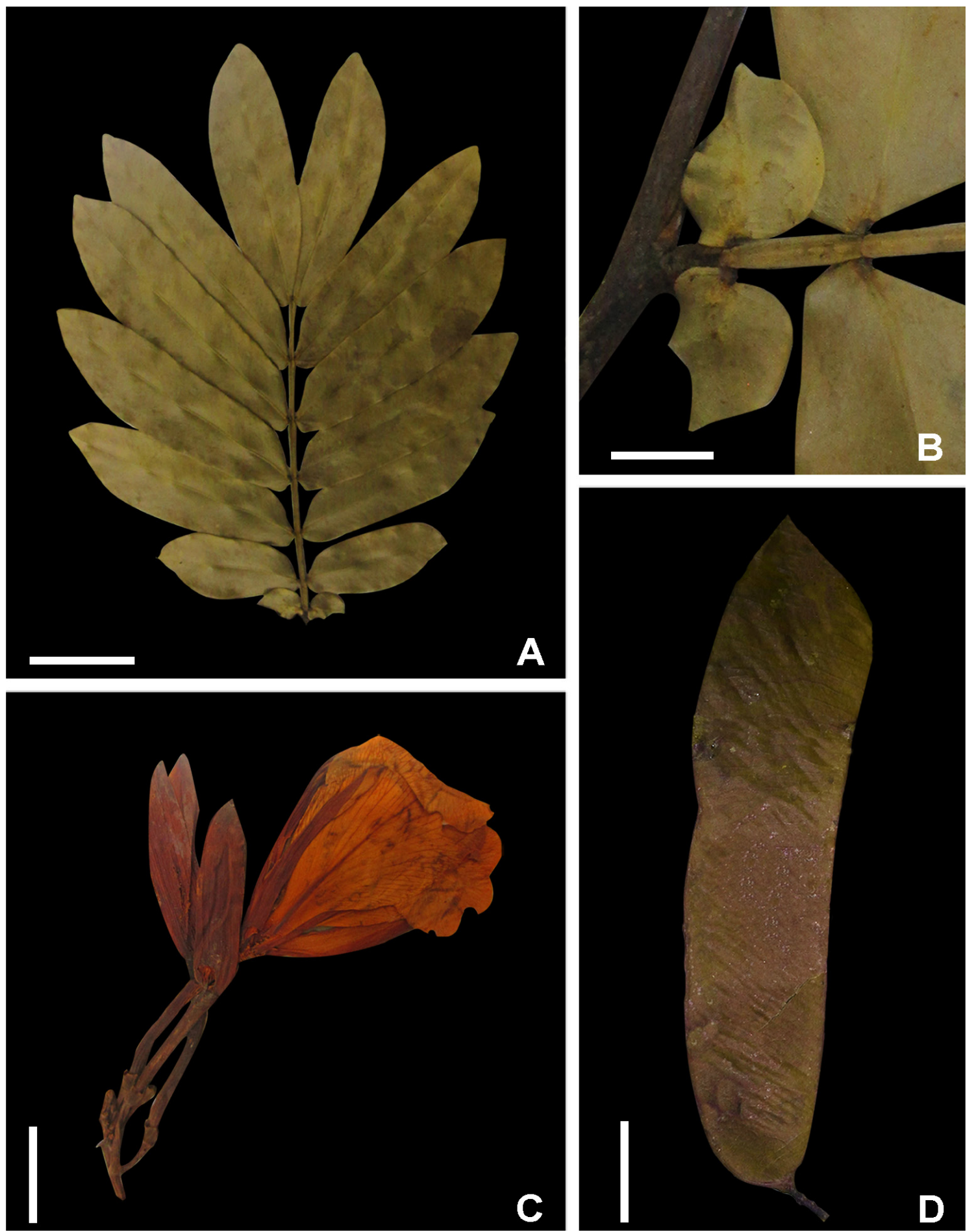

Fig. 2. Heterostemon amoris. A, leaf (Etter 173, COAH). B, basal pair of leaflets (A. Etter 173, COAH). C, flower (P. Franco et al. 6030, COAH). D, fruit. (P. Franco et al. 6030, MO). Scales: A, C, D, $2 \mathrm{~cm} . \mathrm{B}, 0.5 \mathrm{~cm}$. Photograph credits: (A-C) Andrés Fonseca-Cortés, (D) Carolina Romero. Color version at http://www.ojs.darwin.edu.ar/index.php/ darwiniana/article/view/976/1231 
sheath $3.5-4.0 \mathrm{~cm}$ long, inequilateral, filaments 2.0 $3.6 \mathrm{~cm}$ long, anthers $0.3-0.5 \times 0.3-0.5 \mathrm{~cm}$, ovary $3-4 \times 0.5-0.8 \mathrm{~cm}$, ovoid, glabrous, gynophore $0.4-$ $0.5 \mathrm{~cm}$ long, style $2.5-4.0 \mathrm{~cm}$ long, stigma capitate. Pod oblong, flat, $16-20 \mathrm{~cm}$ long $\times 3-5 \mathrm{~cm}$ wide $\times$ $0.1-0.3 \mathrm{~cm}$ thick, glabrous or brown puberulous, with a hook in the apex. Seeds unknown.

Distribution and habitat. Heterostemon amoris is endemic to the Colombian Guiana shield, restricted to the departments of Vaupés and Guainía (Fig. 3). This species grows in humid lowland riverine forests and in 2-3 month flooded forests with a canopy of $15 \mathrm{~m}$, trees up to $40 \mathrm{~cm}$ in diameter and a dense understory with abudant litter $(D$. Cárdenas et al. 44188, COAH).

Etymology. The specific epithet amoris commemorates the love and affection that feels the author of this species for a very special person of his life.

Notes. The description of $H$. amoris increases the number of species of Heterostemon to eight, four of them found in Colombia.

Heterostemon amoris is the only species of the genus known with 5-7 pairs of leaflets. The rest of the species have 1-4 leaflets or 7-27 pairs. Despite some populations of $H$. mimosoides may present seven pairs of leaflets (Fig. 4D), these are oblong being ovate to obovate in $H$. amoris, and the basal pair is only slightly shorter than the rest, being considerably smaller in $H$. amoris.

Heterostemon amoris grows in sympatry with H. conjugatus Spruce ex Benth., H. ellipticus Mart. ex Benth., and H. mimosoides from which it differs by the characters listed in Table 1 and Fig. 4.

The type specimen of $H$. amoris has been identified as Elizabetha fanshawei R.S. Cowan (Cárdenas López et al., 2009; Bernal, 2016). This last species, now a synonym of Paloue fanshawei (R.S. Cowan) Redden, is endemic to Guyana (Redden et al. 2018), and it is clearly distinguished from $H$. amoris by the characters listed in the Table 1 .

Conservation status. The EOO got an area of $8671 \mathrm{~km}^{2}$ and the AOO of $16 \mathrm{~km}^{2}$. Heterostemon amoris meets the requirements under criterion $\mathrm{B}$ for threatenedspecies $\left(\mathrm{AOO}<2,000 \mathrm{~km}^{2}\right)(\mathrm{IUCN}, 2019)$.

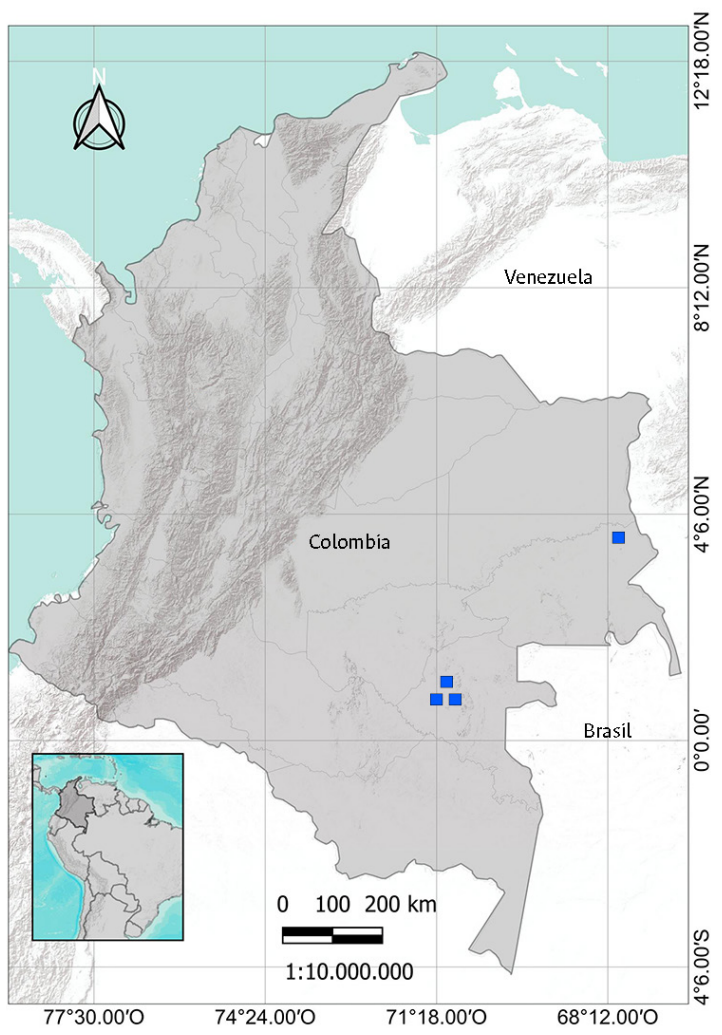

Fig. 3. Distribution map of Heterostemon amoris. Map credits: Jairo A. Peña-Torrés \& Andrés Fonseca-Cortés.

However, this species has only been collected in four localities separated by ca. $400 \mathrm{~km}$, three from the department of Vaupés and one from the department Guainía, so this species could also occur in southern Colombia and in the Brazilian or Venezuelan part of the Guiana shield. For this reason, the Data Deficient (DD) category is proposed for this species (IUCN, 2019).

\section{Specimens examined}

Paratypes. COLOMBIA. Guainía. Puerto Inírida, río Inírida, caño Bocón entre Yarí y caño Guaribea, 20 m, 28-III-1996, A. Etter et al. 173 (COAH). Vaupés. Municipio de Carurú, río Vaupés, margen izquierda, frente a la comunidad de Puerto Nuevo, 320 m, 4-IX2013, D. cárdenas et al. 44188 (COAH); Carurú, margen derecha del río Vaupés, sector Dos Islas, 2-IX-2017, M. Jaimes 1547 (COAH); Carurú, gran resguardo del Vaupés, zonal ASATIQ, cabecera caño Pato, acceso por caño Bacatí, 196 m, 4-XI-2018, $A$. Juméne et al. 142 (COAH). 

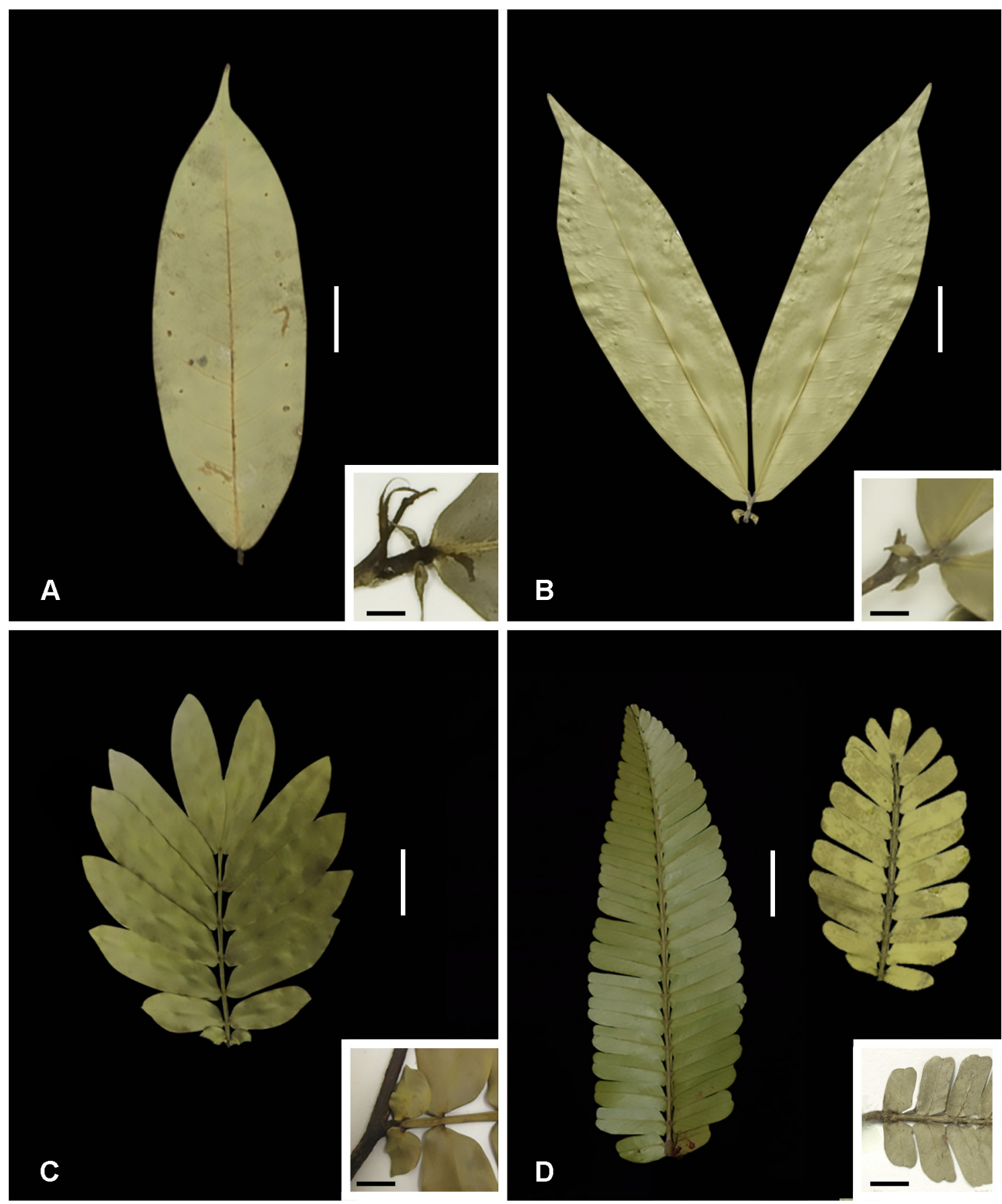

Fig. 4. Leaves from the species of Heterostemon present in Colombia, in each box a detail of the basal pair of leaflets. A, H. ellipticus (D.W. Stevenson et al. 1025, NY; box D.C. Daly et al. 4336, NY). B, H. conjugatus (L. Williams 14526, US; box L. Williams 14338, F.). C, H. amoris (A. Etter 173, COAH; box A. Etter 173, COAH). D, H. mimosoides (left E. Prata s.n., INPA; right B. Maguire et al. 36638, NY; box, D.G. Campbell P20877, US). Scales: white $2 \mathrm{~cm}$, black $0.5 \mathrm{~cm}$. Photograph credits: A, C. V. Starr Virtual Herbarium. B, Smithsonian Institution and Field Museum of Natural History. C, Andrés Fonseca-Cortés. D, Francisco Farronay, C. V. Starr Virtual Herbarium, and Smithsonian Institution. Color version at http://www.ojs.darwin.edu.ar/index.php/darwiniana/article/view/976/1231 
Table 1. Morphological differences between the species of Heterostemon present in Colombia and Paloue fanshawei (R.S. Cowan) Redden.

\begin{tabular}{|c|c|c|c|c|c|}
\hline CHARACTER & H. conjugatus & H. ellipticus & H. mimosoides & H. amoris & P. fanshawei \\
\hline $\begin{array}{l}\text { Number of pairs } \\
\text { of leaflets }\end{array}$ & $1-2$ & $\begin{array}{l}\text { Unifoliolate } \\
\quad \text { or } 11 / 2\end{array}$ & $7-27$ & $5-7$ & $4-6$ \\
\hline $\begin{array}{l}\text { Terminal leaflet } \\
\text { length }(\mathrm{cm})\end{array}$ & $10-30$ & $8-29$ & $1.2-2.7$ & $3.8-5.5$ & $2.7-3.5$ \\
\hline $\begin{array}{l}\text { Terminal leaflet } \\
\text { width }(\mathrm{cm})\end{array}$ & $3-11$ & $3.6-8.0$ & $0.3-0.5$ & $1.1-2.0$ & $1.2-1.4$ \\
\hline $\begin{array}{c}\text { Terminal leaflets } \\
\text { shape }\end{array}$ & Ovate to obovate & Elliptical & Oblong & Ovate to obovate & Ovate \\
\hline Leaflet apex $(\mathrm{cm})$ & Acuminate & Acuminate & Emarginate & $\begin{array}{c}\text { Acuminate to } \\
\text { slightly emarginate }\end{array}$ & Emarginate \\
\hline Basal leaflets & $\begin{array}{l}\text { Stipel-like and } \\
\text { falcate or absent }\end{array}$ & $\begin{array}{l}\text { Stipel-like and } \\
\text { falcate }\end{array}$ & $\begin{array}{l}\text { Slightly shorter } \\
\text { and oblong }\end{array}$ & $\begin{array}{c}\text { Considerably } \\
\text { smaller and falcate }\end{array}$ & $\begin{array}{l}\text { Similar to the } \\
\text { remaining leaflets }\end{array}$ \\
\hline $\begin{array}{c}\text { Number of } \\
\text { developed petals }\end{array}$ & 3 & 3 & 3 & 3 & 1 \\
\hline Petal color & Lilac & Lilac & Lilac & Lilac & White \\
\hline $\begin{array}{c}\text { Number of fertile } \\
\text { stamens }\end{array}$ & 3 & 3 & 3 & 3 & 9 \\
\hline
\end{tabular}

\section{Key to the species of Heterostemon}

1. Leaves with 7-27 pairs of oblong leaflets H. mimosoides Desf.

1. Leaves with $\leq 7$ pairs of elliptical, ovate or obovate leaflets ...................................................................... 2

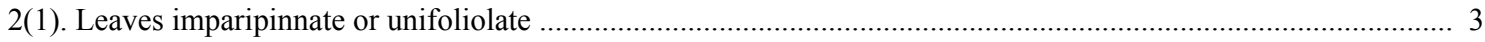

2. Leaves paripinnate

H. impar Spruce ex Benth.

3(2). Basal leaflets with well-developed lamina, persistent

3. Basal leaflets stipel-like, sometimes deciduous and then the leaves appearing simple or unifoliolate

H. ellipticus Mart. ex Benth.

4(2). Leaves with 5-7 pairs of leaflets

H. amoris Fonseca-Cortés

4. Leaves with 1-2 pairs of leaflets

5

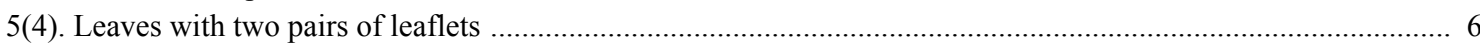

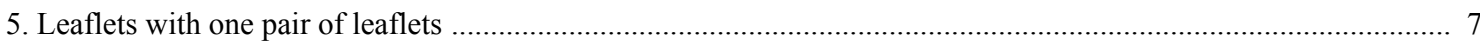

6(5). Both pairs of leaflets well-developed ............................................................................. H. ingifolius Sandwith

6. Only the terminal pair of leaflets with well-developed lamina, the basal reduced to falcate stipel-like leaflets

H. conjugatus Spruce ex Benth.

7(5). Stipules 2-6 $\times 0.9-2.2 \mathrm{~cm}$, auriculate; rachis $1.2-2.0 \mathrm{~cm}$ long

H. otophorus Sandwith

7. Stipules $0.8-1.0 \times 0.1-0.2 \mathrm{~cm}$, lanceolate; rachis $0.1-0.4 \mathrm{~cm}$ long H. mazarunensis Sandwith

\section{ACKNOWLEDGEMENTS}

The author is thankful to the anonymous reviewers for their valuable comments, to Karen Redden for the initial help with the manuscript, to the Reflora Project for the scanning of some herbarium specimens of Heterostemon, and to Carolina Romero, Francisco Farronay, the Field Museum, the New York Botanical Garden and the Smithsonian Institution for sharing their photographs of the Heterostemon.

\section{BIBLIOGRAPHY}

Bentham, G. 1871. Heterostemon. Flora Brasiliensis 15(2): 214-217.DOI: https://doi.org/10.5962/bhl.title.454

Bernal, R. 2016 (continously updated). Elizabetha fanshawei Cowan. In Bernal, R.; S. R. Gradstein \& M. Celis (eds.). Catálogo de plantas y líquenes de Colombia. Instituto de Ciencias Naturales, Universidad Nacional de Colombia, Bogotá. Published on the internet: http://catalogoplantasdecolombia.unal.edu.co/es/ resultados/especie/Elizabetha\%20fanshawei/ [June 2021]. 


\section{A. FONSECA-CORTÉS. A new species of Heterostemon from Colombia}

Cárdenas López, D; N. Castaño Arboleda \& S. Sua Tunjano. 2009. Flora de la Estrella Fluvial de Inírida (Guainía, Colombia). Biota Colombiana 10 (1-2): 1-30.

Cowan, R. S. 1976. A taxonomic revision of the genus Heterostemon (Leguminosae: Caesalpiniodeae). Proceedings of the Koninklijke Nederlandse Akademie van Wetenschappen 79(1): 42-59.

Cowan, R. S. \& P. E. Berry. 1998. Heterostemon. In Steyermark, J.A.; P. E. Berry \& B. K. Holst (eds.). Flora of the Venezuelan Guayana, pp. 67-69. St. Louis: Missouri Botanical Garden.

De Queiroz, K. 2007. Species concepts and species delimitation. Systematic Biology 56: 879-886. DOI: https:// doi.org/10.1080/10635150701701083

IUCN. 2019. Guidelines for using the IUCN Red List Categories and Criteria. Version 14. Prepared by the Standards and Petitions Subcommittee. Published on the internet: http://www. iucnredlist.org/documents/RedListGuidelines.pdf [June 2021].

Gradstein, S. R. 2016 [continuously updated]. Heterostemon. In Bernal, R.; S. R. Gradstein \& M. Celis (eds.). Catálogo de plantas y líquenes de Colombia. Instituto de Ciencias Naturales, Universidad Nacional de Colombia, Bogotá. Published on the internet: http://catalogoplantasdecolombia. unal.edu.co/es/resultados/genero/heterostemon/ [June 2021].

Mackinder, B. 2005 Detarieae. In Lewis, G. P.; B. Schire, B. Mackinder \& M. Lock (eds.). Legumes of the world, pp. 69109. London: Kew.

McDade, L. A. 1995. Species concepts and problems in practice: insight from botanical monographs. Systematic Botany 20: 606-622. DOI: https://doi.org/10.2307/2419813
Murphy, B.; M. de la Estrella, R. Schley, F. Forest \& B. Klitgård. 2018. On the Monophyly of Macrolobium Schreb., an ecologically diverse Neotropical tree genus (FabaceaeDetarioideae). International Journal of Plant Sciences 179(1): 75-86. DOI: https://doi.org/10.1086/695338

Quiñones, L. M. 2005. Leguminosas subfamilia Caesalpiniodeae. In Forero, E \& C. Romero (eds). Estudios en Leguminosas Colombianas, pp. 301-328. Bogotá D.C.: Academia Colombiana de Ciencias Exactas Físicas y Naturales Colección Jorge Álvarez Lleras No 25.

Redden, K. M. \& P. S. Herendeen. 2006. Morphology and phylogenetic analysis of Paloue and related genera in the Brownea clade (Detarieae, Caesalpinioideae). International Journal of Plant Sciences 167(6):1229-1246. DOI: https:// doi.org/10.1086/508065

Redden, K. M.; P. S. Herendeen \& G. P. Lewis. 2018. Understanding Paloue (Leguminosae: Detarioideae). Revision of a predominantly Guiana shield endemic. Smithsonian Washington D.C.: Institution Scholarly Press.

Sandwith, N. Y. 1939. Contributions to the flora of tropical America: XXXIX. Results of a recent collecting expedition to British Guiana. Bulletin of miscellaneous information 1939 (1): 8-9.

Thiers, B. M. 2021 [continuously updated]. Index Herbariorum, A global directory of public herbaria and associated staff. New York Botanical Garden, Bornx, New York. Published on the internet: http://sweetgum.nybg.org/science/ih/ [June 2021].

Wiens, J. J. \& M. R. Servedio. 2000. Species delimitation in systematics: inferring diagnostic differences between species. Proceedings of the Royal Society B 267: 631-636. 